\title{
FRACTIONING OF BARK OF Pinus pinea BY MILLING AND CHEMICAL CHARACTERIZATION OF THE DIFFERENT FRACTIONS
}

\author{
Isabel Miranda ${ }^{1, \star}$, Inês Mirra ${ }^{1}$, Jorge Gominho ${ }^{1}$, Helena Pereira ${ }^{1}$
}

\begin{abstract}
The bark of stone pine (Pinus pinea) from 50 year old trees grown in Portugal was submitted to grinding and fractioning into different particles sizes. The trees had a thick bark with an average 3,7 $\mathrm{cm}$ constituted mainly by the periderm and rhytidome $(3,2 \mathrm{~cm})$. The bark fractured easily into particles: yield of fines was low, and $74,0 \%$ of the particles were over $2 \mathrm{~mm}$. The chemical composition, as a mass weighed average of all granulometric fractions showed a content of $1,1 \%$ ash $20,6 \%$ extractives ( $91 \%$ of which polar extractives) $2,2 \%$ suberin, $43,0 \%$ lignin and $37,6 \%$ holocellulose. The percentage of material dissolved by extraction with $1 \% \mathrm{NaOH}$ was $42,3 \%$. The chemical characterization of the different granulometric fractions showed that extractives were present preferentially in the finest fractions ( $<80$ mesh and 60-80 mesh), representing 34-35\%, particularly with enrichment in ethanol soluble extractives, that also showed lower content of lignin. The coarser fractions contained higher proportions of lignin and holocellulose. P. pinea bark grinding and fractionation by particle size may be used to selectively enrich the finest fractions in soluble materials, while the coarser fractions tend to have higher holocellulose content and will be therefore more suitable for carbohydrate related uses.
\end{abstract}

Keywords: Extractives, holocellulose, lignin, particle size, Stone pine.

\section{INTRODUCTION}

Valorisation of forest residual biomass is a strategic issue in line with present preoccupations regarding forest sustainability and overall ecological footprint of materials and energy. This applies in the case of barks generated from forest operations and industrial processing. Barks are important raw-materials due to the large potential available amounts as well as to their structural and chemical complexity that make them well suited to integrate biorefinery platforms. Prior to processing, barks may undergo pre-treatments, namely of physical nature, to facilitate the subsequent component extraction or material use (Wyman 1996). For instance the mechanical fractioning disrupts the cellular tissues and may be used to separate fractions of differing composition but fraction yields depend on the particular species anatomy and physical characteristics (Miranda et al. 2012, Miranda et al. 2013).

In this study we address the case of the stone pine bark. Stone pine (Pinus pinea) is a native pine of Southern Europe and an important species in the Mediterranean region. It is especially valued for the production of an edible seed as well as for wood production; other products include resin, bark tannins, and the empty pine cones are popular as biofuel. P. pinea is also cultivated for environmental protection i.e. consolidation of coastal dunes, soil conservation and protection of coastal agricultural crops. The tree has an attractive aspect with a rather spherical crown and is frequently used as ornamental in parks 
and green areas.

The Iberian Peninsula accounts for approximately $75 \%$ of the total P. pinea stands: Spain has 464000 ha (BDN 2008) and Portugal 130300 ha (ICNF 2013). The species also occurs in Turkey (40000 ha), Italy (40000 ha), Tunisia (15000 ha), France (13515 ha), Morocco (3000 ha) and Israel (2000 ha) (Loewe et al. 2011). The average production of pine nuts in Spain and Portugal is about 7000 tones year ${ }^{-1}$, and represents 40 to $60 \%$ of the world production of pine nuts (including nuts from other pine species).

The stone pine has a thick scale bark of strong brown reddish colour that represents $7 \%$ of the aboveground biomass (Correia et al. 2010). The bark is composed of three structural layers: secondary phloem, the innermost periderm and the rhytidome (Nunes et al. 1999). The secondary phloem includes sieve cells, axial parenchyma and rays, and resin ducts are present in fusiform rays. The rhytidome has a variable number of periderms forming scale-type discontinuous layers with a thin phellem of two to four layers of thick-walled cork cells and sclerified cells (Nunes et al. 1999). P. pinea bark shows a considerable amount of tannins and relatively low content of polysaccharides and lignin, making it attractive as a potential source of polyphenols (Nunes et al. 1999).

This paper studies the fractionation by grinding and the granulometric separation of stone pine bark (P. pinea). The fractions with different particle sizes were characterized in relation to bulk density, ash content and chemical composition, with the objective to analyze the potential of granulometric fractioning for selective component enrichment within a biorefinery route of bark use.

\section{MATERIAL AND METHODS}

\section{Sampling and fractioning}

Samples of bark from stone pine (Pinus pinea L.) were collected from four trees with 50 years of age with an overbark diameter at 1,3 m from 47,0 to 64,4 cm, from Herdade dos Leitões, Ponte de Sôr, in Portugal. The bark was removed by manual debarking of a strip with approximately $6 \mathrm{~cm}$ of height at 1,3 $\mathrm{m}$ of tree height. Bark thickness was measured and separated into the inner phloem and periderm and rhytidome.

After air-drying at ambient conditions, the bark was fractionated using a knife mill (Retsch SM2000) with an output sieve of $10 \times 10 \mathrm{~mm}^{2}$. Particle size and particle size distribution of the ground bark were determined according to ASAE S319.3. The granulometric fractioning of the ground bark was made using a vibratory sieving apparatus (Retsch AS 200 basic) composed of U.S. standard wire sieves numbers 10,15,20,40, 60 and 80 (sieve opening sizes: $2 ; 1 ; 0,850 ; 0,425 ; 0,250$ and $0,180 \mathrm{~mm}$, respectively) with a 10-minute sieve shaking time. After sieving, the mass retained on each sieve was weighed and the corresponding mass fraction yields were determined. The sieve analysis was repeated three times.

\section{Bulk density}

The bulk density of the ground bark samples was measured following the standard method ASAE S269.4 DEC01. The bulk density of each sieve fraction was calculated, using a cylindrical container $(29,8 \mathrm{~mm}$ height $\mathrm{x} 28,1 \mathrm{~mm}$ diameter), as the ratio of the mass sample, in the container to the volume of the container. Each measurement was repeated three times with the same bark sample. 


\section{Microscopic observations}

The different granulometric fractions of the bark samples were observed by optical microscopy after cell dissociation by maceration in a 1:1 glacial acetic acid:hydrogen peroxide solution, and staining with astra blue.

\section{Chemical characterization}

Chemical summative analyses included determination of ash, extractives soluble in dichloromethane, ethanol and water, suberin, klason and acid soluble lignin, and holocellulose. The unextracted original bark was used to determine $1 \% \mathrm{NaOH}$ solubles. The granulometric fraction with particle size over 2 $\mathrm{mm}$ was carefully ground prior to chemical analysis in order to obtain particles that passed through the $0,425 \mathrm{~mm}$ (40 mesh) sieve. Each chemical determination was made in duplicated samples.

Ash content was determined according to TAPPI test methods (TAPPI T $211 \mathrm{om}-02$ ) by complete incineration of $2,0 \mathrm{~g}$ of the sample in a muffle furnace at $525^{\circ} \mathrm{C}$ overnight and the residues weighed and reported as a percentage of the original samples.

The alkaline lixiviation with $1 \% \mathrm{NaOH}$ was carried out in a stirred glass reactor with reflux using $1,0 \mathrm{~g}$ of material with a 1:50 solid:liquid ratio, at $100^{\circ} \mathrm{C}$ and 1 hour contact time.

Solvent extraction was performed in a Soxhlet extractor using $2 \mathrm{~g}$ of the sample successively with dichloromethane, ethanol and water during $6 \mathrm{~h}, 16 \mathrm{~h}$ and $16 \mathrm{~h}$ respectively. The extractives solubilised by each solvent were determined using the mass difference from the mass of the solid residue after drying at $105^{\circ} \mathrm{C}$, and reported as a percentage of the original samples (TAPPI T204 om-88).

Suberin content was determined on 1,5 $\mathrm{g}$ of extractive-free material by refluxing with $100 \mathrm{ml}$ of a $3 \% \mathrm{NaOCH}_{3}$ solution in $\mathrm{CH}_{3} \mathrm{OH}$ during $3 \mathrm{~h}$ (Pereira 1988). The sample was filtrated, washed with methanol, again refluxed with $100 \mathrm{ml} \mathrm{CH} \mathrm{CH}_{3} \mathrm{OH} 15 \mathrm{~min}$ and filtrated. The combined filtrates were acidified to $\mathrm{pH} 6$ with $2 \mathrm{~mol} \mathrm{dm}^{-3} \mathrm{H}_{2} \mathrm{SO}_{4}$ and evaporated to dryness. The residue was suspended in 50 $\mathrm{ml}$ water and the alcoholysis products recovered with dichloromethane in three successive extractions, each with $50 \mathrm{ml}$ dichloromethane. The combined extracts were dried over anhydrous $\mathrm{Na}_{2} \mathrm{SO}_{4}$ and evaporated to dryness. The suberin extracts, that include the fatty acid and fatty alcohol monomers of suberin, were quantified gravimetrically, and the results expressed in percent of the initial dry mass.

Klason lignin (TAPPI T222 om-02) and acid-soluble lignin (TAPPI UM 250) contents were determined on the extracted and desuberinised materials. Sulphuric acid $(72 \% ; 3,0 \mathrm{ml})$ was added to $0,35 \mathrm{~g}$ of the material sample, and the mixture was placed in a water bath at $30^{\circ} \mathrm{C}$ for $1 \mathrm{~h}$ after which the sample was diluted to a concentration of $3 \% \mathrm{H}_{2} \mathrm{SO}_{4}$ and hydrolysed for $1 \mathrm{~h}$ at $120^{\circ} \mathrm{C}$. The sample was vacuum-filtered through a crucible and washed with boiling purified water. Klason lignin was determined as the mass of the solid residue after drying at $105^{\circ} \mathrm{C}$. The acid-soluble lignin was determined on the combined filtrate by measuring the absorbance at $206 \mathrm{~nm}$ using a UV/VIS spectrophotometer.

The holocellulose content of extractive-free and desuberinised samples was determined by the chlorite method (Rowell 2005). $1 \mathrm{~g}$ of sample was placed in an Erlenmeyer flask (300 ml) and $32 \mathrm{ml}$ of distilled water was added. While slowly shaking, $0,750 \mathrm{~g}$ of $\mathrm{NaClO}_{2}$ and $0.3 \mathrm{ml}$ of acetic acid were added and the flask was covered with glass and boiled at 70 to $80^{\circ} \mathrm{C}$ for $60 \mathrm{~min}$. Again, $0,750 \mathrm{~g}$ of $\mathrm{NaClO}_{2}$ and $0,3 \mathrm{ml}$ of acetic acid were added and boiled three times. After cooling, the sample was filtered using a filter flask and washed with $50 \%$ cold water and acetone until free of acid. Afterwards, the insoluble portion was dried in an oven at $105^{\circ} \mathrm{C}$ for $4 \mathrm{~h}$, cooled in a desiccator and weighed repeatedly until obtaining a constant weight.

\section{Statistical analysis}

Differences between granulometric fractions were tested with a one-way ANOVA, by applying pairwise analysis (Tukey test, $\mathrm{p}<0,05$ ). 


\section{RESULTS AND DISCUSSION}

\section{Bark fractioning}

P. pinea has on average a $3,7 \mathrm{~cm}$ thick dark of reddish brown colour with a very high proportion of a scale-type rhytidome and a comparatively thin phloem layer that measured on average $0,6 \mathrm{~cm}$. It was possible to visually distinguish within the rhytidome the different periderms interspersed by the phloem layers that become isolated after the underneath formation of each periderm.

The observed bark thickness was in the range reported by Rigolot (2004) who refers 0,9 to $4,4 \mathrm{~cm}$ thickness for $P$. pinea bark in trees with an overbark diameter at $1,3 \mathrm{~m}$ ranging 5,7 to $58,1 \mathrm{~cm}$.

The yields obtained for the different granulometric fractions of stone pine bark after milling and their bulk density and ash content are summarized in Table 1. The results show that stone pine bark is brittle and fractures easily into particles with a low yield of fines, i.e. $74,0 \%$ of the particles were over $2 \mathrm{~mm}$. This is in accordance with the dominance of the rhytidome in the bark and to its fracture characteristics related to the presence of highly sclerified cells (Nunes et al. 1999).

Table 1. Mass yield (\%) after grinding and granulometric separation of stone pine (Pinus pinea L.) bark and bulk density $\left(\mathrm{kg} / \mathrm{m}^{3}\right)$ and ash content (\% of total dry mass) of the different granulometric

fractions.

\begin{tabular}{|c|c|c|c|}
\hline Fraction $(\mathrm{mm})$ & Mass yield (\%) & Bulk density $\left(\mathrm{kg} / \mathrm{m}^{3}\right)$ & Ash content $(\%)$ \\
\hline$<0,180$ & 2,2 & 293,7 & 1,5 \\
\hline $0,180-0,250$ & 2,5 & 223,9 & 1,5 \\
\hline $0,250-0,425$ & 3,3 & 211,6 & 1,5 \\
\hline $0,450-0,850$ & 5,7 & 200,1 & 1,1 \\
\hline $0,850-1,00$ & 2,3 & 272,5 & 1,0 \\
\hline $1,00-2,00$ & 9,9 & 225,0 & 1,0 \\
\hline$>2,00$ & 74,0 & 209,6 & 1,1 \\
\hline Mean \pm stand. dev. & & $233,8 \pm 35,3$ & $1,2 \pm 0,2$ \\
\hline
\end{tabular}

Other pine barks also showed upon fractioning a predominance of large particles, although in a smaller extent than the results found here for P. pinea. For P. sylvestris bark the major fractions corresponded to large particles (50,3\% of particles over $2 \mathrm{~mm}$ ) (Miranda et al. 2012). For P. pinaster bark, the major fractions were also large particles $(37,6 \%$ of $0,5-1,0 \mathrm{~mm}$ particles) (Vázquez et al. 1987a).

The fractions obtained for the stone pine bark had an average bulk density of $234 \mathrm{~kg} / \mathrm{m}^{3}$. The differences in density between fractions were small and did not show a clear trend of variation with particle size. Very little information exists on bark bulk density and in some cases the determination method is not specified. For ground bark from P. sylvestris mean values of $202 \mathrm{~kg} / \mathrm{m}^{3}$ (Miranda et al. 2012) and $263 \mathrm{~kg} / \mathrm{m}^{3}$ (Wieczorek 2008) were reported. Zapata et al. (2005) referred $250 \mathrm{~kg} / \mathrm{m}^{3}$ for ground $P$. pinea bark with particle size below $8 \mathrm{~mm}$. Bulk density of different pine bark fractions was only reported by Miranda et al. (2012) for P. sylvestris who showed a small variation of bulk density between granulometric fractions with an average value of $202 \mathrm{~kg} / \mathrm{m}^{3}$.

The ash content of the bark was low at an average 1,1\% (Table 1). Nunes et al. (1999) had reported $2,3 \%$ for $P$. pinea bark. In other pine barks values of $1-4 \%$ were referred for $P$. sylvestris bark (Harju et al. 2002, Werkelin et al. 2005, Saarela et al. 2005, Miranda et al. 2012) 1,8\% for P. brutia (Akyuz et al. 2003) and 0,5-1,2\% for P. pinaster (Vázquez et al. 1987b, Nunes et al. 1996).

We found only a small difference in ash content between the fractions, with the higher values in the fractions with the smaller particle size (Table 1). Frequently there is a higher ash content in the fines, because the small and grindable inorganic constituents tend to accumulate in the finer sized fraction (Bridgeman et al. 2007, Liu and Bi 2011). This effect is more important when there is contamination of 
bark with soil particles as it may be the case with barks collected at mills that may have considerable amounts of entrapped minerals (Miranda et al. 2013). This was not the case here since the bark was collected directly from the stem of the trees.

\section{Bark chemical composition}

The chemical composition of the stone pine bark, calculated as a mass weighed average of all granulometric fractions is shown in Table 2 . The bark had 20,7\% extractives, corresponding mainly to polar extractives that were removed with ethanol and water $(91 \%$ of the total extractives). Lignin content was $42,7 \%$ and holocellulose content $37,0 \%$. The percentage of material dissolved by the direct alkaline extraction of bark with $1 \% \mathrm{NaOH}$ was $42,4 \%$. Suberin content was low at $2 \%$. This value fits well with the small amount of phellem tissue in the periderms of the rhytidome (Nunes et al. 1999).

Table 2. Summative chemical composition (\% o.d. material) of the stone pine (Pinus pinea) bark, of three granulometric fractions : fine $(\mathrm{F},<0,180 \mathrm{~mm})$, medium $(\mathrm{M}, 0,250-0,450 \mathrm{~mm})$ and coarse $(\mathrm{C}$, $>2 \mathrm{~mm}$ ) and of a mean bark composition (weighed mean with fraction yield).

\begin{tabular}{|c|c|c|c|c|}
\hline & Mean & F & M & C \\
\hline Ash & 1,1 & 1,5 & 1,5 & 1,1 \\
\hline Extractives & & & & \\
\hline Total & 20,7 & 33,7 & 23,7 & 20,1 \\
\hline Dichloromethane & 1,8 & 2,6 & 3,3 & 1,7 \\
\hline Ethanol & 9,4 & 23,8 & 14,8 & 8,5 \\
\hline Water & 9,4 & 7,3 & 5,6 & 9,9 \\
\hline Suberin & 2,1 & 1,4 & 1,6 & 2,2 \\
\hline Lignin & & & & \\
\hline Total & 42,7 & 35,1 & 36,5 & 44,0 \\
\hline Klason & 42,2 & 34,6 & 35,8 & 43,5 \\
\hline Acid soluble & 0,5 & 0,5 & 0,7 & 0,5 \\
\hline Holocelulose & 37,0 & 30,2 & 31,7 & 38,1 \\
\hline $1 \%$ NaOH & 42,4 & 70,3 & 46,8 & 41,3 \\
\hline
\end{tabular}

These results are similar to those referred to in the only reference found on the chemical composition of $P$. pinea bark (Nunes et al. 1999): 19,1\% total extractives (which $63 \%$ were extractible with ethanol and water), 2,5\% suberin, 37,5\% lignin and 36,8\% polysaccharides. Compared to other Pinus species, the extractives content of $P$. pinea bark obtained here was higher than the values reported for P. sylvestris (18,8 \% (Miranda et al. 2012)), and P. pinaster (18,0\% (Vázquez et al. 1987a) 16,6\% (Fradinho et al. 2002), 11,4\% (Nunes et al. 1996)). The lignin content was similar to the value of $33,7 \%$ reported by Miranda et al. (2012) for $P$. sylvestris bark and to the 34,2 - 33,2\% for P. pinaster bark (Vázquez et al. 1987a, Fradinho et al. 2002), but higher than the $24,9 \%$ reported for $P$. densiflora bark (Kofujita et al. 1999) to the 20-35\% for Pinus radiata bark (Moya-Villablanca et al. 2013) and to the $25,5 \%$ for Pinus brutia (Sahin and Arslan 2011). The holocellulose content obtained here was similar to the values of 37,6\% and 40,1\% reported for P. sylvestris bark (Miranda et al. 2012, Valentín et al. 2010) and 48,4\% for P. pinaster bark (Fradinho et al. 2002) and higher than the $25,0-32,1 \%$ reported by Vázquez et al. (1987b) for P. pinaster bark, however for the $P$. brutia bark Sahin and Arslan (2011) refer to higher values of holocellulose $74,5 \%$. When stone pine bark was extracted with $1 \%$ $\mathrm{NaOH}$ about $42,4 \%$ of the bark material was solubilized. The mass removed by alkaline lixiviation corresponds mostly to soluble polyphenols broadly called phenolic acids, to compounds obtained from suberin and wax depolymerization as well as to some labile polysaccharides (Vázquez et al. 1987b, Kofujita et al. 1999). In the case of $P$. pinea bark, and given its composition (Table 2), the alkaline extracts should be mostly of phenolic nature. 
These results are in agreement with the amounts of alkaline extractable material referred for softwood barks. Miranda et al. (2012) mentioned that 50,4\% of P. sylvestris bark was dissolved by $1 \%$ $\mathrm{NaOH}$ extraction, Vázquez et al. (1987a) reported 20,6\% material loss by the direct alkaline extraction of P. pinaster bark, and Kofujita et al. (1999) referred that 49,7\% of P. densiflora bark was dissolved by $1 \% \mathrm{NaOH}$ extraction.

A note of caution should however be given when comparing chemical contents of barks. Overall there are relatively few studies on the chemical composition of pine barks, and usually they differ as regards analytical methods and sample preparation procedures, which may impact on the specific results given the structural and chemical complexity of barks.

\section{Effect of particle size on bark chemical composition}

The milled stone pine bark samples were chemically characterized and Table 2 gives the results for three fractions: $<0,180 \mathrm{~mm}$ (fine) 0,250 - 0,450 $\mathrm{mm}$ (medium) and $>2 \mathrm{~mm}$ (coarse) (Table 2).

A particle size effect was observed on the content and composition of extractives (Figure 1). Extractives were present preferentially in the finest fraction due to an enrichment in polar compounds soluble in ethanol i.e. $33,7 \%$ in comparison with $20,1 \%$ for the coarser fraction. Water solubles showed an increased proportion in the coarse fraction, representing $49 \%$ of the total (Figure 1). However the difference among granulometric fractions for the median values of extractives was not statistically significant.

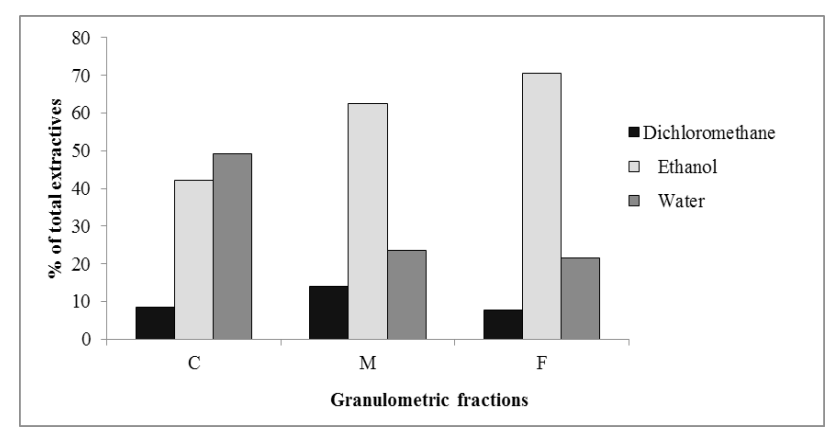

Figure 1. Proportion of total extractives soluble in three solvents (dichloromethane, ethanol and water) of Pinus pinea bark milled to the granulometric fractions of fine (F, $<0,180 \mathrm{~mm}$ ), medium (M $0,250-0,450 \mathrm{~mm})$ and coarse $(\mathrm{C},>2 \mathrm{~mm})$ particles.

Lignin and holocellulose contents showed statistically significant differences between fractions and were highest in the coarse fraction: $44,0 \%$ lignin and 38,1\% holocellulose, in comparison with $35,1 \%$ and $30,2 \%$ respectively in the fine fraction (Figure 2 ). 


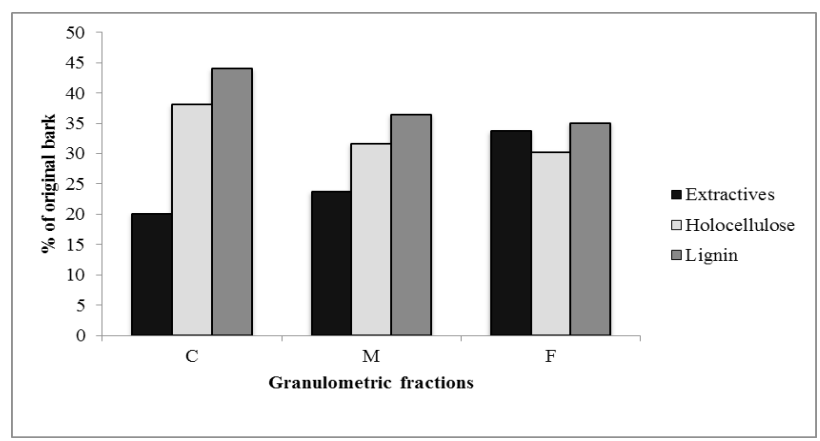

Figure 2. Proportion of total extractives, holocellulose and lignin (\% o.d. material) of the stone pine (Pinus pinea) bark milled to the granulometric fractions of fine $(\mathrm{F},<0,180 \mathrm{~mm})$, medium (M 0,250 $0,450 \mathrm{~mm})$ and coarse $(\mathrm{C},>2 \mathrm{~mm})$ particles.

The milling process did not randomly reduce the different components of the bark in a uniform manner. Bark consists of tissues with different anatomical and physical properties that condition the distribution of sizes after grinding and the differences in the chemical composition of the bark fractions (Franceschi et al. 2005, Vázquez et al. 2001. For instance the sieve cells and parenchyma cells of phloem have mostly only primary cell walls and are easily fractured by mechanical processes, therefore preferentially enriching the fines. These cells are involved in the physiological processes of transport and storage and should have a high content of extractives, as it was found in the fines (Table 2). On the contrary, the sclerenchyma cells act as supporting elements and have a lignified cell wall that provides mechanical strength.

The observations using optical microscopy confirmed that the cells types that were contained in the particles of the fine fraction of $<80$ mesh were predominantly parenchyma and sieve cells that originated from the phloem (Figure 3). This is in agreement with the finding that this fraction has comparatively lower lignin content and higher extractives (Table 2). The other fractions had a different cellular composition including abundant schlereids that are grouped in clusters. These cells are present in the rhytidome in the intersperced phloem layers between periderms and result from the dilatation and wall thicknening of parenchyma cells (Figure 4).

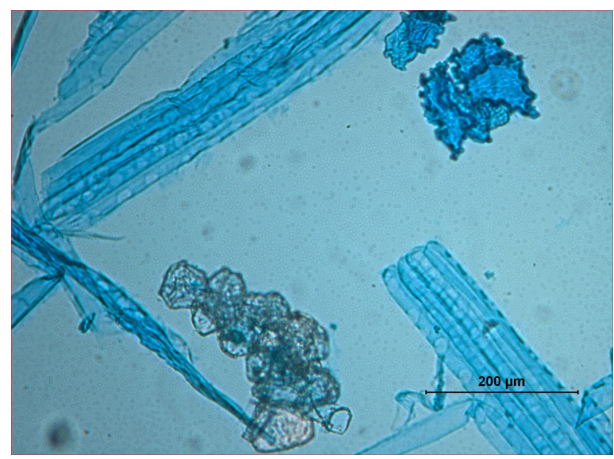

Figure 3. Microscopic observations of dissociated cells obtained from the $<0,180 \mathrm{~mm}$ granulometric fraction after fractioning of Pinus pinea bark. 


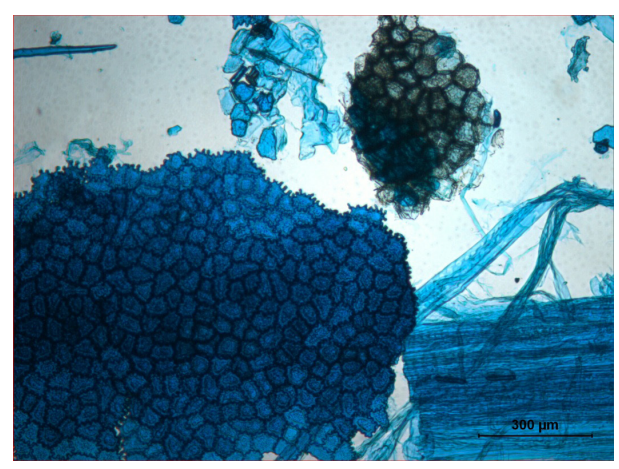

Figure 4. Microscopic observations of dissociated cells obtained from the $0,250-0,450 \mathrm{~mm}$ granulometric fraction after fractioning of Pinus pinea bark.

Bridgeman et al. (2007) also reported that the process of size reduction does not apply in a uniform manner to the different components of biomass, and that cellulose, hemicelluloses and lignin tend to remain in the larger sized particle fraction. Tamaki and Mazza (2010) and Chundawat et al. (2007) showed that protein and extractives content decrease with increasing particle size, hemicelluloses and glucan contents increase while lignin content did not show clear trends. Ottone and Baldwin (1981) also reported that extractives increased with decreasing particle size in milled yellow-poplar bark and depended on the relative amounts of phloem and outer bark.

The results showed that for $P$. pinea bark grinding and fractionation by particle size are unit operations that may be used to selectively enrich the finest fractions in soluble materials. The coarser fractions tend to have higher holocellulose content and will be therefore more suitable for carbohydrate related uses.

However, when envisaging using mechanical fractioning of $P$. pinea bark for separating fractions i.e. using fines as a potential source of polar extractables, it should be noted that the generation of fines is of small magnitude ( $8 \%$ of $<0,5 \mathrm{~mm}$ particles).

\section{CONCLUSIONS}

The bark of Pinus pinea fractured easily into particles with a low yield of fines. Bulk density and ash content of the different granulometric fractions were similar.

The bark was chemically characterized by a significant content of extractives that included mainly polar compounds that could be extracted by solvent solubilisation. Alkaline lixiviation with $1 \% \mathrm{NaOH}$ also led to a high mass loss of over $50 \%$. Extraction processes may therefore be considered for a selective component removal from these barks.

$P$. pinea bark grinding is influenced by its structural and chemical features and fractionation by particle size may be used to selectively enrich the fine fractions in soluble materials. The coarser fractions tend to have higher holocellulose content and will be therefore more suitable for carbohydrate related uses. 


\section{ACKNOWLEDGEMENTS}

This work is part of the research activities of Centro de Estudos Florestais (CEF), a research unit supported by FCT - Fundação para a Ciência e a Tecnologia (UID/AGR/00239/2013). We thank Dr. Teresa Quilhó for her help in interpreting the bark anatomical features. We also wish to thank Fundação João Lopes Fernandes - Herdade dos Leitões who kindly provided the samples used in this study.

\section{REFERENCES}

Akyuz, M.; Sahin, A.; Alma, A.; Bektap, I.; Usta, A. 2003. Conversion of tree bark into bakelitelike thermosetting materials by phenolation. In: XII World Forest Congress. Québec City Canada. 0425-A1

BDN. 2008. Annual forestry statistics. Gobierno de España, Madrid. [Available at] $<\mathrm{http}: / / w w w$. mapama.gob.es/es/desarrollorural/estadisticas/forestal_estructura_2008.aspx>

Bridgeman, T.G.; Darvell, L.I.; Jones, J.M.; Williams, P.T.; Fahmi, R.; Bridgwater, A.V.; Barraclough, T.; Shield, I.; Yates, N.; Thain, S.C.; Donnison, I.S. 2007. Influence of particle size on the analytical and chemical properties of two energy crops. Fuel 86(1-2):60-72.

Chundawat, S.P.S.; Venkatesh, B.; Dale, B.E. 2007. Effect of particle size based separation of milled corn stover on AFEX pretreatment and enzymatic digestibility. Biotechnology Bioengineering 96(2):219-231.

Correia, A.C.; Tomé, M.; Pacheco, C.A.; Faias, S.; Dias, A.C.; Freire, J.; Carvalho, P.O.; Pereira, J.S. 2010. Biomass allometry and carbon factors for a Mediterranean pine (Pinus pinea L.) in Portugal. Forest Systems 19(3):418-433.

Fradinho, D.M.; Pascoal Neto, C.; Evtuguin, D.; Jorge, F.C.; Irle, M.A.; Gil, M.H.; Pedrosa de Jesus, J. 2002. Chemical characterization of bark and of alkaline bark extracts from maritime pine grown in Portugal. Industrial Crops and Products 16:23-32.

Franceschi, V.R.; Krokene, P.; Christiansen, E.; Krekling, T. 2005. Anatomical and chemical defenses of conifer bark against bark beetles and other pests. New Phytologist 167:353-376

Harju, L.; Saarela, K.E.; Rajander, J.; Lill, J.O.; Lindroos, A.; Heselius, S.J. 2002. Environmental monitoring of trace elements in bark of Scots pine by thick-target PIXE. Nuclear Instruments and Methods in Physics Research Section B 189:163-167.

ICNF. National Forest Inventory Continental Portugal. 2013. ICNF 2013. Inventário Florestal Nacional (Portugal Continental) Lisboa, Portugal. Available at $<$ http://www.icnf.pt/portal/florestas/ifn/ ifn6>.

Kofujita, H.; Ettyu, K.; Ota, M. 1999. Characterization of the major components in bark from five Japanese tree species for chemical utilization. Wood Science and Technology 33:223-228.

Liu, X.; Bi, X.T. 2011. Removal of inorganic constituents from pine barks and switch grass. Fuel Processing Technology 92(7):1273-1279.

Loewe, V.M.; Delard, C.R.; Venegas, A.G. 2011. Pine nut (Pinus pinea L.) production, an alternative for temperate areas. APANews; FAO Regional Office for Asia and the Pacific 39:4-7.

Miranda, I.; Gominho, J.; Mirra, I.; Pereira, H. 2012. Chemical characterization of barks from Picea abies and Pinus sylvestris after fractioning into different particle sizes. Industrial Crops and Products 36:395-400.

Miranda, I.; Gominho, J.; Mirra, I.; Pereira, H. 2013. Fractioning and chemical characterization of barks of Betula pendula and Eucalyptus globulus. Industrial Crops and Products 41: 299-305. 
Moya-Villablanca, C.; Oses-Pedraza, R.; Poblete-Wilson, H.; Valenzuela-Hurtado, L. 2013. Effects of wood and bark flour content of Pinus radiata on the accelerated decay of wood-plastic composites. Maderas. Ciencia y Tecnología 16(3):37-48.

Nunes, E.; Quilho, T.; Pereira, H. 1996. Anatomy and chemical composition of Pinus pinaster bark. IAWA Journal 17(2):141-149.

Nunes, E.; Quilhó, T.; Pereira, H. 1999. Anatomy and chemical composition of Pinus pinea. L. bark. Annals of Forest Science 56:479-484.

Ottone, S.; Baldwin, R.C. 1981. The relationship of extractive content to particle size distribution In milled yellow-poplar (Liriodendron tulipifera L.) bark. Wood and Fiber Science 13(2):74-85.

Pereira, H. 1988. Variability in the chemical composition of plantation eucalypts (Eucalyptus globulus Labill.). Wood and Fiber Science 20(1):82-90.

Rigolot, E. 2004. Predicting postfire mortality of Pinus halepensis Mill. and Pinus pinea L. Plant Ecology 171:139-151. USA.

Rowell, R.M. 2005. Handbook of Wood Chemistry and Wood Composites. CRC Press: Madison

Saarela, K.-E.; Harju, L.; Rajander, J.; Lill, J.-O.; Heselius, S.J.; Lindroos, A.; Mattsson, K. 2005. Elemental analyses of pine bark and wood in an environmental study. Science of the Total Environment 343:231-241.

Sahin, H.T.; Arslan, M.B. 2011. Weathering performance of particleboards manufactured from blends of forest residues with Red pine (Pinus brutia) wood. Maderas. Ciencia y Tecnología 13(3):337346.

Tamaki, Y.; Mazza, G. 2010. Measurement of structural carbohydrates, lignins, and microcomponents of straw and shives: Effects of extractives, particle size and crop species. Industrial Crops and Products 31:534-541.

Valentín, L.; Kluczek-Turpeinen, B.; Willför, S.; Hemming, J.; Hatakka, A.; Steffen, K.; Tuomela, M. 2010. Scots pine (Pinus sylvestris) bark composition and degradation by fungi: Potential substrate for bioremediation. Bioresources and Technology 101:2203-2209.

Vázquez, G.; Parajó, J.C.; Antorrena, G. 1987a. Sugars from pine bark by enzymatic hydrolysis. Effect of sodium chlorite treatments. Wood Science and Technology 21: 167-178.

Vázquez, G.; Antorrena, G.; Parajó, J.C. 1987b. Studies on the utilization of Pinus pinaster bark. Part 1: Chemical constituents. Wood Science and Technology 21:65-74.

Vázquez, G.; González-Alvarez, J.; Freire, S.; López-Suevos, F.; Antorrena, G. 2001. Characteristics of Pinus pinaster bark extracts obtained under various extraction conditions. Holz als Roh und Werkstoff 59:451-456.

Werkelin, J.; Skrifvars, B.J.; Hupa, M. 2005. Ash-forming elements in four Scandinavian wood species. Part 1: Summer harvest. Biomass and Bioenergy 29:451-466.

Wieczorek, S. 2008. Assessing the influence of adsorbent bed (tree bark) parameters on the reduction of ammonia emission from animal husbandry. Polish J Environ Stud 17(1):147-154.

Wyman, CE. 1996. Handbook on Bioethanol: Production and Utilization, Applied Energy Technology Series. Taylor \& Francis, Washington DC.

Zapata, N.; Guerrero, F.; Polo, A. 2005. Evaluation of pine bark and urban wastes as componentes of plant growth media. Agricultura Técnica 65(4):378-487. 